\title{
Prevalence of bovine brucellosis, paratuberculosis, enzootic leucosis, and antigen-reactive agents to bovine viral diarrhea virus in animals up to one year old
}

\section{Frequência de brucelose bovina, paratuberculose, leucose enzoótica bovina e antígeno-reagentes para diarreia viral bovina em bovinos com até um ano de idade}

\author{
Hernando Andres Munoz Carrillo ${ }^{1}$; Sarah Regina Bezerra Silveira ${ }^{2}$; Augusto Sousa \\ Miranda $^{3}$; Érika Dayane Leal Rodrigues ${ }^{4}$; Felipe Masiero Salvaranis*
}

\begin{abstract}
Live cattle export is one of the newest commercial sectors available to Brazilian farmers, but to be exported animals must be free of infectious diseases, especially those prohibited by the countries importing them. In this study, 1,800 bovine sera were collected from animals destined for export in the Brazilian states of Goiás (GO), Minas Gerais (MG), and São Paulo (SP). The sera were tested for bovine brucellosis (BB), paratuberculosis (PTB), enzootic bovine leukosis (EBL), and bovine viral diarrhea (BVD). This was the first study in Brazil to conduct a serological survey for bovine PTB in the states of SP, GO, and MG, and the first survey for BVD in GO. The total percentage of animals positive for each disease was $0.33 \%(2 / 1,800)$ for BB, $16.17 \%(97 / 1,800)$ for PTB, $31.50 \%(189 / 1,800)$ for EBL, and $9.67 \%(58 / 1,800)$ for BVD.
\end{abstract}

Key words: Sanitary control. Disease. International trade. Animal transit.

\section{Resumo}

\begin{abstract}
A exportação de bovinos vivos é uma das novas áreas comerciais em que o Brasil está inserido, porém é necessário que os animais sejam livres de doenças infectocontagiosas, principalmente as exigidas pelos países importadores. Os 1800 soros utilizados neste estudo foram de bovinos dos Estados de Goiás (GO), Minas Gerais (MG) e São Paulo (SP), que seriam destinados à exportação. Foram realizados os diagnósticos sorológicos para brucelose bovina (BB), paratuberculose (PTB), leucose enzoótica bovina (EBL) e diarreia viral bovina (BVD), sendo este o primeiro trabalho no Brasil a realizar o levantamento sorológico para PTB em bovinos nos Estados de SP, GO e MG, e de BVD em GO. A porcentagem total de animais positivos para cada uma das patologias foi de $0,33 \%(2 / 1800)$ para BB; $16,17 \%(97 / 1800)$ para PTB; 31,50\% (189/ 1800) para EBL e 9,67\% (58/1800) para BVD.

Palavras-chave: Controle sanitário. Doença. Comércio internacional. Trânsito animal.

\footnotetext{
${ }^{1}$ Discente de Doutorado em Biologia de Agentes Infecciosos e Parasitários, Universidade Federal do Pará, UFPA, Belém, PA, Brasil. E-mail: mv.hamc@gmail.com

2 Médica Veterinária, Universidade Federal Rural da Amazônia, UFRA, Belém, PA, Brasil. E-mail: saraHsilveira100@hotmail. com

3 M.e em Ciência Animal, UFPA, Castanhal, PA, Brasil. E-mail:augusto@veterinario.med.br

4 Discente de Mestrado em Biologia de Agentes Infecciosos e Parasitários, UFPA, Belém, PA, Brasil. E-mail:erikadlr@ufpa.br

5 Prof. Dr., Universidade Federal do Pará, UFPA, Castanhal, PA, Brasil. E-mail: felipems@ufpa.br

* Author for correspondence
} 
Brazil has diversified its economic activities in the livestock sector to become more competitive in the global market. It exported approximately $1,103,494$ head of live cattle to countries including Venezuela, Egypt, Turkey, Angola, Iraq, Jordan, and Lebanon between 2011 and 2016 (BRASIL, 2016). However, this market has strict requirements to control the spread of infectious diseases, such as bovine brucellosis (BB), paratuberculosis (PTB), bovine viral diarrhea (BVD), and enzootic bovine leukosis (EBL), as stipulated by the World Organisation for Animal Health. Given the growing demand for live cattle in the export market, it is important that the health of these animals is monitored with serological surveys for diseases of commercial interest. Obtaining these data will make the local epidemiological situation more transparent, and eventually allow for the sanitary certification of the exporting states or regions to be achieved. In addition, such transparency will help to continuously update the sanitary status of each specific region of the country. Therefore, the objective of this study was to determine the prevalence of animals seropositive for BB, PTB, and EBL, as well as antigen-reactive agents to BVD, in a population of animals up to one year old destined for live export.

We analyzed 1,800 samples from a bovine serum bank made available by the GRANVET laboratory. The samples were collected from Angus, Braford, and Hereford cattle aged between 8 and 12 months and with live weights of 230-290 kg. All animals were male, eliminating the risk of interference from passively transferred maternal antibodies. These animals came from beef farms authorized by the state animal welfare body, which have continuous veterinary follow-up and follow a sanitary calendar that includes obligatory and optional vaccinations and deworming treatments. The 1,800 sera came from cattle in the states of Goiás (GO), Minas Gerais (MG), and São Paulo (SP), Brazil, with 600 samples obtained from each state.

The diagnostic protocol used included the buffered acid antigen test (BAAT) to detect BB antibodies (BRASIL, 2006). Enzyme-linked immunosorbent assay (ELISA) was used (according to the manufacturer's recommendations) along with commercial IDEXX kits to detect BVD (BVDV Ag/Serum Plus ${ }^{\circledR}$ ), antibodies against the EBL virus (Leukosis Serum Screening $\mathrm{Ab}^{\circledR}$ ), and antibodies against Mycobacterium avium subsp. paratuberculosis (MAP) (Paratuberculosis Screening $\left.\mathrm{Ab}^{\circledR}\right)$.

The results obtained in this study are compiled in Table 1. The serodiagnosis results showed that $0.33 \%$ of young male animals from eight to 12 months of age were seropositive for BB in the samples from MG, while animals seropositive for BB were absent in the samples from GO and SP. Mota et al. (2016) conducted a similar study in the same states, but with female animals over 24 months of age, and reported occurrences of animals seropositive for BB of $16.2 \%(145 / 895)$ in $\mathrm{GO}, 6.6 \%(145 / 2,204)$ in $\mathrm{MG}$, and $9.8 \%(105 / 1,073)$ in SP. These data suggest that the actual prevalence of $\mathrm{BB}$ in the studied regions is higher than that suggested by the data obtained herein for the population of males destined for export. The difference between the occurrence of this disease in young males destined for beef production and adult females in both studies agrees with the BB epidemiology and exposure of cattle to risk factors in Brazil presented by Alencar et al. (2016). However, new representative serological surveys of the male population between eight and 12 months of age are needed to determine the actual prevalence of $\mathrm{BB}$ in each state and the consequent real $\mathrm{BB}$ sanitary situation. Obtaining these data, together with information on risk factors in this bovine population, could contribute to the establishment of new control and eradication strategies in the National Program for the Control and Eradication of Brucellosis and Tuberculosis (PNCEBT) for young males destined for export. They would also help to define which states need more help to implement this program to clear international trade restrictions in the male bovine market. 
There is little data in the literature on bovine PTB serological surveys in Brazil, and the present study was the first in Brazil to conduct a serological survey of PTB in the states of GO, MG, and SP. PTB is diagnosed more frequently in dairy cattle than in beef cattle due to the longer exposure of dairy animals to sources of infection, such as chronically infected adult animals, contaminated pastures, and other elements that may carry MAP and be used as transmission agents, thus increasing the infection rates and prevalence of this disease (FISS et al., 2015; ROSSI et al., 2017). This may be the reason for the low occurrence of this disease in the present study, in which only 5.33 and $5.50 \%$ of the sera from young male cattle from eight to 12 months of age were seropositive for PTB.

Table 1. Number and percentage of bovine serum samples reactive to the presence of antibodies against bovine brucellosis (BB), paratuberculosis (PTB), and enzootic bovine leukosis (EBL), as well as antigen-reactive agents to the presence of bovine viral diarrhea (BVD) virus, in male Angus, Braford, and Hereford animals between eight and 12 months of age destined for export.

\begin{tabular}{lccccc}
\hline & No. of samples & BB $^{1}$ & PTB $^{2}$ & BVD $^{3}$ & EBL $^{4}$ \\
\hline GOIÁS & 600 & $0(0.0 \%)$ & $32(5.3 \%)$ & $18(3.0 \%)$ & $89(14.8 \%)$ \\
\hline MINAS GERAIS & 600 & $2(0.3 \%)$ & $33(5.5 \%)$ & $14(2.3 \%)$ & $33(5.5 \%)$ \\
\hline SÃO PAULO & 600 & $0(0.0 \%)$ & $32(5.3 \%)$ & $26(4.3 \%)$ & $67(11.2 \%)$ \\
\hline TOTAL & 1,800 & $2(0.1 \%)$ & $97(5.4 \%)$ & $58(3.2 \%)$ & $189(10.5 \%)$ \\
\hline
\end{tabular}

${ }^{1}$ Buffered acid antigen test (AAT)

${ }^{2}$ Enzyme-linked immunosorbent assay (ELISA) for the detection of bovine viral diarrhea virus antigens (BVDV Ag/Serum Plus ${ }^{\circledR}$ )

${ }^{3}$ ELISA for the detection of antibodies against bovine leukosis virus (Leukosis Serum Screening $\mathrm{Ab}^{\circledR}$ )

${ }^{4}$ ELISA for the detection of antibodies against MAP (Paratuberculosis Screening $\mathrm{Ab}^{\circledR}$ ).

Previous studies conducted PTB serodiagnoses in other Brazilian states, and found that the occurrence of seropositive animals aged 24 months or older was 34.5\% (864/2,504) in Paraíba (VILAR et al., 2015) and to identify risk factors associated with herd-level prevalence for bovine paratuberculosis in the State of Paralu00edba, Northeastern Brazil. The state was divided into three sampling groups: sampling stratum 1 (mesoregion of Sertlu00e3o, 2.7\% (11/408) in Pernambuco (SÁ et al., 2013), 14.7\% (5/34) in in Rio Grande do Sul (FISS et al., 2015), and $13.2 \%(165 / 1,450)$ in Espírito Santo (COSTA et al., 2010). Compared to the abovementioned results, those of the present study showed a relatively lower prevalence of seropositive animals, although these are results for populations that differed in terms of both their gender and age. However, when analyzed together the data showed that young cattle destined for beef production may also be infected by MAP and, therefore, could participate in the epidemiological chain of infection in the region studied. In addition, from the commercial point of view the identification of potentially infected young animals may lead to export restrictions, justifying the study of specific disease control measures in this bovine population.

The 1,800 cattle analyzed in this study had no history of BVD vaccination. Diagnostic tests showed that $3 \%$ of the animals in GO were positive for specific bovine viral diarrhea (BVD) virus antigens of genotypes I and II. In MG, $2.33 \%$ of the young male animals presented antigens detectable by ELISA, and in SP $4.33 \%$ of the 600 samples were positive. Brazilian studies of BVD typically analyze the detection of antibodies against BVD virus, meaning that seropositive animals may have presented negative results in the ELISA test used in this study. Although Dias et al. (2010) conducted a serological screening to detect antibodies against BVD virus in animals from six to 12 months of age from 26 herds in SP and MG, they could only 
identify two persistently infected (PI) animals using a polymerase chain reaction technique preceded by reverse transcription (RT-PCR), which makes further comparisons between that study and the present one difficult due to the different methods used. However, more studies on BVD, with larger samples and in different Brazilian states, are greatly needed, since BVD may represent an obstacle for live cattle export by the country. In addition, different sanitary situations should be considered, as there are different international sanitary requirements in the different countries importing cattle, including requirements for certificates stating that animals were non-reactive for the presence of BVD virus antigens at the time of testing and that the herd is free of animals reactive to the presence of antibodies against BVD virus that, from a sanitary point of view, could guarantee greater biological safety for the importing country.

Among the epidemiological studies conducted in Brazil to determine the presence and distribution of EBL virus infection, Angelino et al. (1998) reported that disease prevalence was associated with the age of the animal. They found lower numbers of animals positive for EBL in the age group between six and 12 months of age than in adult animals, which was likely due to the longer exposure of adults to sources of infection. This fact was corroborated by Camargos et al. (2002), who determined the frequency of seropositive cattle in herds from $\mathrm{MG}$ and concluded that more extensive beef farms have lower occurrences of infection compared to dairy farms. This may explain the low percentages of young male animals aged eight to 12 months that were positive for EBL in the present study $(14.83 \%$ in $\mathrm{GO}, 5.5 \%$ in $\mathrm{MG}$, and $11.17 \%$ in $\mathrm{SP}$ ), which agreed with the result of Camargos et al. (2002), in which only $1.8 \%(2 / 112)$ of animals from seven to 19 months of age were seropositive. The analysis of the results of this study, together with the data from the abovementioned previous surveys, suggested that animals destined for beef production between eight and 12 months of age may also be seropositive for EBL, representing a sanitary risk in the studied regions potentially leading to export restrictions. This justifies the need for further studies of specific control and prevention measures in this group of the bovine population.

Considering the results found in the present study, we concluded that young male cattle from eight to 12 months of age destined for beef production in $\mathrm{GO}$, MG, and SP presented antibodies against BB, PTB, and $\mathrm{EBL}$, as well as antigens against the BVD virus, in their sera. It is therefore necessary to conduct new epidemiological surveys in all of the Brazilian states to determine the actual sanitary status of these diseases there, especially in the sampled age group, so that Brazil can better compete in the global live animal export market.

\section{Acknowledgements}

This study was financed in part by the Coordenação de Aperfeiçoamento de Pessoal de Nível Superior - Brasil (CAPES) - Finance Code 001, Conselho Nacional de Desenvolvimento Científico e Tecnológico (CNPq), Fundação Amazônia de Amparo a Estudos e Pesquisa (FAPESPA) and Universidade Federal do Pará (UFPA).

\section{References}

ANGELINO, J. L. D.; GARCIA, M.; BIRGEL, E. H. Epidemiological study of enzootic bovine leukosis in Brazil. Tropical Animal Health and Production, Edinburgh, v. 30, n.1, p. 13-15, 1998.

BRASIL. Programa Nacional de Controle e Erradicação da Brucelose e da Tuberculose Animal (PNCEBT). Brasília: MAPA/SDA/DSA, 2006. 192 p.

Plataforma para consulta dos dados estadísticos de comercio exterior brasileiro-Comex Stat. 2016. Disponível em: $<$ http://comexstat.mdic.gov.br/>. Acesso em: 1 jun. 2016.

CAMARGOS, M. F.; MELO, C. B.; LEITE, R. C.; STANCEK, D.; LOBATO, Z. I. P.; ROCHA, M. A.; SOUZA, G. N.; REIS, J. K. P. Frequência de soropositividade para leucose enzoótica bovina em 
rebanhos de Minas Gerais. Ciência Veterinaria nos Trópicos, Recife, v. 5, n. 1, p. 20-26, 2002.

COSTA, J. C. M.; PIERI, F. A.; SOUZA, C. F.; ESPESCHIT, I. F.; FELIPPE, A. G.; SANTOS, G. M.; TOBIA F. L.; SILVA JÚNIOR, A.; MOREIRA, M. A. S. Levantamento sorológico de Mycobacterium avium subsp. paratuberculosis em bovinos leiteiros no estado do Espiríto Santo. Arquivo Brasileiro de Medicina Veterinária e Zootecnia, Belo Horizonte, v. 62, n. 6, p. 1491-1494, 2010.

DIAS, F. C.; MÉDICI, K. C.; ALEXANDRINO, B.; MEDEIROS, A. S. R.; ALFIERI, A. A.; SAMARA, S. I. Ocorrência de animais persistentemente infectados pelo vírus da diarréia viral bovina em rebanhos bovinos nos estados de minas gerais e São Paulo. Pesquisa Veterinária Brasileira, Seropédica, v. 30, n. 11, p. 933-939, 2010.

FISS, L.; SANTOS, B. L.; ALBUQUERQUE, P. P. F; MOTA, R. A.; MARCOLONGO-PEREIRA, C.; ADRIEN, M. L; SOARES, M. P.; SCHILD, A. L. Paratuberculose em bovinos de corte na região Sul do Rio Grande do Sul. Pesquisa Veterinária Brasileira, Seropédica, v. 35, n. 5, p. 437-442, 2015.

MOTA, A. L. A.; FERREIRA, F.; FERREIRA NETO, J. S.; DIAS, R. A.;AMAKU, M.; GRISI-FILHO, J. H. H.;
TELLES, O. E.; GONÇALVES, V. P. Large-scale study of herd-level risk factors for bovine brucellosis in Brazil. Acta Tropica, Netherlands, v. 164, p. 226-232, 2016.

ROSSI, G. DE LEO, G. A.; PONGOLINI, S.; NATALINI, S.; ZARENGHI, L.; RICCHI, M.; BOLZONI, L. The potential role of direct and indirect contacts on infection spread in dairy farm networks. PLoS Computational Biology, San Francisco, v. 13, n. 1, p. 1-19, 2017.

SÁ, L. D. M.; OLIVEIRA, J. M. B.; SANTOS, G. R.; BRANDESPIM. D. F.; SILVA JÚNIOR, J. L.; MOTA, R. A.; PINHEIRO JÚNIOR, J. W. Avaliação sorológica e de fatores de risco para a infecção por Mycobacterium avium subsp. paratuberculosis em rebanhos leiteiros da Microrregião de Garanhuns, Pernambuco. Pesquisa Veterinária Brasileira, Seropédica, v. 33, n. 3, p. 310$313,2013$.

VILAR, A. L. T.; SANTOS, C. S . A. B.; PIMENTA, C. L. R. M.; FREITAS, T. D.; BRASIL, A. W. L.; CLEMENTINO, I. J.; ALVES, C. J.; BEZERRA, C. S.; RIET-CORREA, F.; OLIVEIRA, T. S.; AZEVEDO, S. $\mathrm{S}$. Herd-level prevalence and associated risk factors for Mycobacterium avium subsp. paratuberculosis in cattle in the State of Paraíba, Northeastern Brazil. Preventive Veterinary Medicine, Colorado, v. 121, n. 1-2, p. 49-55, 2015. 
